ISSN : $1225-9918$

\title{
$\beta$-Lapachone-Induced Apoptosis is Associated with Inhibition of Cyclooxygenase-2 Activity in Human Lung Cancer A549 Cells
}

\author{
Yung Hyun Choi*
}

\section{Department of Biochemistry, Dongeui University College of Oriental Medicine, Busan 614-052, and Department of Biomaterial Contrd (BK21 program) and Blue-Bio Industry Regional Innovation Center, Dongeui University, Busan 614-714, Korea}

Received August 12, 2011 /Revised October 15, 2011 /Accepted October 17, 2011

\begin{abstract}
B-lapachone, a quinone of lapachol extracted from the bark of the lapacho tree, has been found to induce apoptosis in various human cancer cells. In the present study, we investigated further possible mechanisms by which $\beta$-lapachone exerts its pro-apoptotic action in cultured human lung cancer A549 cells. $\beta$-lapachone treatment resulted in inhibition of growth and induction of apoptosis in a concentration-dependent manner, as determined by MTT assay and flow cytometry analysis. The induction of apoptosis by $\beta$-lapachone was associated with up-regulation of the expression of p53 and p21 in both transcriptional and translational levels, and the phosphorylation of p53. In addition, $\beta$ -lapachone activated caspase-3 and -9 , and induced degradation of caspase- 3 target proteins such as poly (ADP-ribose) polymerase (PARP) and $\beta$-catenin. Furthermore, $\beta$-lapachone treatment caused a progressive decrease in the expression levels of cyclooxygenase (COX)-2 without significant changes in the levels of COX-1, which was correlated with a decrease in prostaglandin $E_{2}$ synthesis. Taken together, these results indicated that $\beta$-lapachone may have therapeutic potential in human lung cancer treatment.
\end{abstract}

Key words : $\beta$-lapachone, apoptosis, p53, p21, COX-2

\section{서 론}

Programmed cell death로 정의되어지는 apoptosis는 생체 내 불필요하거나 비정상적인 세포의 제거를 위한 능동적인 세포 죽음 형태로서, 최근 암의 치료 및 예방을 위한 수단으로 적극적으로 활용되고 있다. 즉 암세포 특이적 apoptosis를 유 발하는 약물은 새로운 항암제로서의 개발 가능성이 매우 높음 을 의미한다. B-lapachone (3,4-dihydro-2,2-dimethyl-2Hnaphthol[1,2-b] pyran-5,6-dione)은 남미에 자생하는 lapacho 나무(Tabeuia avellanedad)의 수액에서 얻어지는 lipophilic ortho-naphthoquinone 계열 물질로서 DNA topoisomerase I 억 제제로 알려진 이후 다양한 인체 암세포의 증식억제와 더불어 강력한 apoptosis 유도 효과가 있는 것으로 보고되어져 왔다 $[10,11,19]$. 특히 B-lapachone에 의한 암세포의 apoptosis 유도 에는 종양억제유전자 p53의 인산화 및 cyclin-dependent kinase $(\mathrm{CDK})$ 저해제인 $\mathrm{p} 21$ 의 발현 증가와 연관이 있는 것으로 알려져 있었다[2,3,20,22]. 그러나 최근 연구에 의하면 $\beta$ -lapachone에 의한 apoptosis 유도에는 p53 비의존적인 경우 $[12,17]$ 와 또 다른 $\mathrm{CDK}$ 저해제인 $\mathrm{p} 27$ 의 발현 증가가 동반된다 는 보고도 있다[4,7]. 즉 $\beta$-lapachone에 의한 암세포의 증식억 제에는 p53 비의존적인 apoptosis 유도 가능성이 크지만, 여전

\section{*Corresponding author}

Tel : +82-51-850-7413, Fax : +82-51-853-4036

E-mail : choiyh@deu.ac.kr
히 $\mathrm{p} 53$ 의 역할에 대해서는 더 연구할 가치가 있을 것으로 생각 된다. 특히 많은 암세포에서 p53이 돌연변이되었거나 p53 유 전자 자체가 결실된 경우가 많기 때문에 $\mathrm{p} 53$ 이 정상으로 존재 하는 암세포에서 $\mathrm{p} 53$ 의 역할이 중요할 것으로 기대되어지기 때문이다.

한편 cyclooxgenase-2 (COX-2)의 발현 증가와 암의 발생과 의 연관성에 관한 많은 보고들에 의하면, $\mathrm{COX}-2$ 는 초기 정상 세포의 암화 과정에서 매우 중요한 역할을 하는 것은 명백한 현상으로 인식되어지고 있다. 즉 $\mathrm{COX}-2$ 의 발현 증가와 동반 된 지속적인 염증성 자극은 정상세포의 비정상적인 증식 촉진 을 유래하며, 이는 COX-2가 암 예방 및 암의 증식을 막을 수 있는 매우 중요한 표적인자가 될 수 있음을 의미한다[1,6]. Prostaglandin (PG) endoperoxide synthase인 COXs는 arachidonic acid를 PGs 및 다양한 eicosanoids로 대사성 전환에 관여하는 rate-limiting enzyme으로, COX-1이 일정 비율로 생 성되어 항상성 유지에 관여하는 반면, COX-2는 neoplastic transformation, 세포증식, 혈관신생, 침윤 및 전이활성 증가와 연 관된 immediate-early gene의 일종이다[5,6]. 따라서 COX-2 발현의 억제와 PGs의 생성을 저하시킬 수 있는 신물질은 화학 적 암예방제로의 개발 가능성이 매우 높기 때문에 정상 세포 에 독성을 보이지 않는 COX-2 활성 저해능이 뛰어난 천연물 의 탐색과 기전 연구는 많은 관심의 대상이 되고 있다.

최근 본 연구실의 선행 연구에 의하면 $\beta$-lapachone은 인체 전립선 암세포의 증식억제과정에서 COX-2의 발현이 저해되 
었으며[9], 신경교세포에서 endotoxin에 의한 COX-2의 발현 증가 및 $\mathrm{PGE}_{2}$ 의 생성 억제 효능이 있음을 관찰한 바 있으나 [13], 이 과정에서 p53 및 p21이 관여하는지는 확인된 바 없다. 따라서 본 연구에서는 p53이 정상으로 존재하는 A549 인체폐 암세포[14]를 이용하여 B-lapachone에 의한 apoptosis 유도 과 정에서 COX-2 활성 저하에 따른 $\mathrm{PGE}_{2}$ 의 생성 억제가 p53 및 $\mathrm{p} 21$ 의 발현과 어떤 연관성이 있는지를 조사하였다.

\section{재료 및 방법}

\section{세포배양, $\beta$-lapachone의 처리 및 생존율 측정}

본 연구에 사용된 A549 폐암세포(American Type Culture Collection, Rockville, MD)는 10\% fetal bovine serum (FBS)에 $1 \%$ 의 penicillin 및 streptomycin이 포함된 $90 \%$ 의 RPMI- 1640 배지(Gibco BRL, Grand Island, NY)를 사용하여 $37^{\circ} \mathrm{C}, 5 \%$ $\mathrm{CO}_{2}$ 조건 하에서 배양하였다. B-lapachone은 Biomol (Plymouth Meeting, PA)에서 구입하여 ice-cold absolute alcohol에 $10 \mathrm{mM}$ 의 stock solution으로 희석하여 사용하였다. A549 세포의 증식에 미치는 $\beta$-lapachone의 영향을 조사하기 위하여 6 well plate에 A549 세포를 $1 \times 10^{3}$ 개로 분주하고 24시 간 동안 안정화시킨 후, $\beta$-lapachone을 적정량 처리하여 48시 간 동안 배양한 세포를 대상으로 MTT assay를 실시하였다.

\section{Flow cytometry 분석을 통한 apoptosis의 정량적 분석}

적정농도의 B-lapachone이 48시간 처리된 세포들을 모아 Cycle TEST PLUS (Becton Dickinson, San Jose, CA) solution $\mathrm{A}$ 및 $\mathrm{B}$ 를 상온에서 각각 10 분씩 처리한 후, Cycle TEST PLUS solution $\mathrm{C}$ 를 처리하여 $4{ }^{\circ} \mathrm{C}$ 에서 10 분간 염색하였다. 그 후 DNA flow cytometer (BD FACSCalibur)를 사용하여 세포주 기의 histogram을 분석하였다.

Reverse transcription-polymerase chain reaction
(RT-PCR) 분석
동일한 조건에서 배양된 $\mathrm{A} 549$ 세포들에 TRIzol reagent
(Invitrogen Co., Carlsbad, CA)를 $4^{\circ} \mathrm{C}$ 에서 1 시간 동안 처리하

여 RNA를 분리하였다. 분리된 RNA를 정량한 후, 각각의 primer (Table 1), DEPC water 그리고 ONE-STEP RT-PCR PreMix Kit (Intron, Korea)를 넣고 Mastercycler gradient (Eppendorf, Hamburg, Germany)를 이용하여 증폭하였다. 각 $\mathrm{PCR}$ 산물들의 양적 차이를 확인하기 위하여 $1 \mathrm{X} \mathrm{TAE} \mathrm{buffer로}$ $1 \%$ agarose gel을 만들고 well 당 각각의 primer에 해당하는 PCR 산물에 DNA gel loading solution을 섞어서 loading 한 후 $50 \mathrm{~V}$ 에서 전기영동을 행하였다. 전기영동으로 DNA 분리 가 끝난 gel을 ethidium bromide $(\mathrm{EtBr})$ 을 이용하여 염색한 후 UV 하에서 발현의 차이를 확인하였으며, glyceraldehyde-3-phosphate dehydrogenase (GAPDH)를 internal control로 사용하였다.

\section{단백질의 분리, 전기영동 및 Western blotting}

준비된 세포들에 적정량의 lysis buffer $[25 \mathrm{mM}$ Tris-Cl $(\mathrm{pH}$ 7.5), $250 \mathrm{mM} \mathrm{NaCl}, 5 \mathrm{mM}$ EDTA, 1\% NP-40, $1 \mathrm{mM}$ phenylmethylsulfonyfluoride, $5 \mathrm{mM}$ dithiothreitol] 를 첨가하여 $4^{\circ} \mathrm{C}$ 에서 1 시간 반응시킨 후, $14,000 \mathrm{rpm}$ 으로 30 분 원심분리하여 그 상층액을 취하였다. 상층액에서 얻은 단백질을 sodium dodecyl sulphate (SDS)-polyacrylamide gel을 이용하여 전기영 동으로 분리하였다. 분리된 단백질을 함유한 acrylamide gel 을 nitrocellulose membrane (Schleicher and Schuell, Keene, $\mathrm{NH})$ 으로 전이시킨 후, 적정 항체를 처리하여 enhanced cheiluminoscence (ECL) 용액 (Amersham Life Science Corp., Arlignton Heights, IL)을 적용시킨 X-ray film에 감광시켜 특 정단백질의 양을 분석하였다. 본 실험에 사용된 항체들은 Santa Cruz Biotechnology Inc.에서 구입하였으며, caspase-3 (mouse monoclonal)을 제외하고는 모두 rabbit polyclonal 항 체였다. Immunoblotting을 위한 peroxidase-labeled 항체는 Amersham에서 구입하였다.

\section{Prostaglandin $\mathrm{E}_{2}$ 의 측정}

$\mathrm{PGE}_{2}$ 생성량 측정을 위해 사용한 $\mathrm{PGE}_{2} \mathrm{EIA}$ kit는 Cayman Chemicals (Ann Arbor, MI)에서 구입하였다. A549 세포에 다 양한 농도의 B-lapachone를 48시간 동안 처리 후, 상층액만

Table 1. Oligonucleotides used in RT-PCR

\begin{tabular}{lll}
\hline Name & \multicolumn{1}{c}{ Sequence of primers } \\
\hline p53 & $\begin{array}{l}\text { sence } \\
\text { antisence } \\
\text { s21 }\end{array}$ & $5^{\prime}$-GCT-CTG-ACT-GTA-CCA-CCA-TCC-3' \\
& antisence & $5^{\prime}$-CTC-TCG-GAA-CAT-CTC-GAA-GCG-3' \\
coX-1 & $5^{\prime}$-CTC-AGA-GGA-GGC-GCC-ATG-3' \\
& sence & $5^{\prime}$-GGG-CGG-ATT-AGG-GCT-TCC-3' \\
COX-2 & $5^{\prime}$-TGC-CCA-GCT-CCT-GGC-CCG-CCG-CTT-3' \\
& sence & $5^{\prime}$-GTG-CAT-CAA-CAC-AGG-CGC-CTC-TTC-3' \\
GAPDH & $5^{\prime}$-TTC-AAA-TGA-GAT-TGT-GGG-AAA-AT-3' \\
& antisence & $5^{\prime}$-AGA-TCA-TCT-CTG-CCT-GAG-TAT-CTT-3' \\
& sence & $5^{\prime}$-CGG-AGT-CAA-CGG-ATT-TGG-TCG-TAT-3' \\
& antisence & $5^{\prime}$-AGC-CTT-CTC-CAT-GGT-GGT-GAA-GAC-3' \\
\hline
\end{tabular}


이용하여 $\mathrm{PGE}_{2}$ EIA kit에 제시된 방법에 따라 처리한 다음 ELISA reader를 이용한 $420 \mathrm{~nm}$ 의 흡광도로 반응의 정도를 측정하였다.

\section{결과 및 고찰}

A549 세포의 증식에 미치는 $\beta$-lapachone의 영향을 조사하 기 위하여 적정 농도의 $\beta$-lapachone을 48 시간 처리 후 MTT assay를 실시하였다. Fig. $1 \mathrm{~A}$ 에 나타낸 바와 같이 B-lapachone 의 처리 농도가 증가할수록 A549 세포의 생존율은 점차 감소 되어 $5 \mu \mathrm{M}$ B-lapachone 처리군에서는 $80 \%$ 이상의 생존율 저 하 현상을 보였으며, 이는 세포의 다양한 형태적 변형을 동반 하였다(Fig. 1B). 이러한 B-lapachone에 의한 A549 세포의 생 존율 감소가 apoptosis 유도에 의한 것인지의 여부를 조사하 기 위하여 전형적인 apoptosis가 유발된 세포의 정량적 빈도 에 해당되는 세포주기 sub-G1기에 속하는 세포의 빈도를 조사
하였다. Fig. 1C에 나타낸 결과에서 알 수 있듯이 B-lapachone 이 첨가되지 않은 배지에서 배양된 sub-G1기 빈도는 약 $1.28 \%$ 임에 비하여 4 및 $5 \mu \mathrm{M}$ ß-lapachone 처리군에서 약 14.97 및 $40.81 \%$ 로 매우 증가되었다. 이는 $\beta$-lapachone 처리에 의한 A549 세포의 증식억제가 apoptosis 유도와 연관되어 있음을 보여 주는 결과이다.

B-lapachone에 의한 A549 세포의 증식억제 및 apoptosis 유발과정에서 p53 및 p21의 발현 변화가 동반되는지의 여부를 조사하기 위하여 $\beta$-lapachone이 48시간 처리된 세포를 대상 으로 RT-PCR 및 Western blotting 분석을 실시하였다. Fig. $2 \mathrm{~A}$ 에서 알 수 있듯이 B-lapachone의 처리 농도가 증가할수록 p53 및 p21 mRNA의 발현이 모두 증가하였으며, 단백질 수준 에서의 두 유전자 발현도 모두 $\beta$-lapachone 처리 농도 의존적 으로 증가하였으며, 특히 인산화형 p53 (Ser15)의 발현 증가가 동반되었다(Fig. 2A). 이는 p53이 정상으로 존재하는 암세포에 서 $\beta$-lapachone의 처리에 의한 암세포의 증식억제 및 apopto-
A)

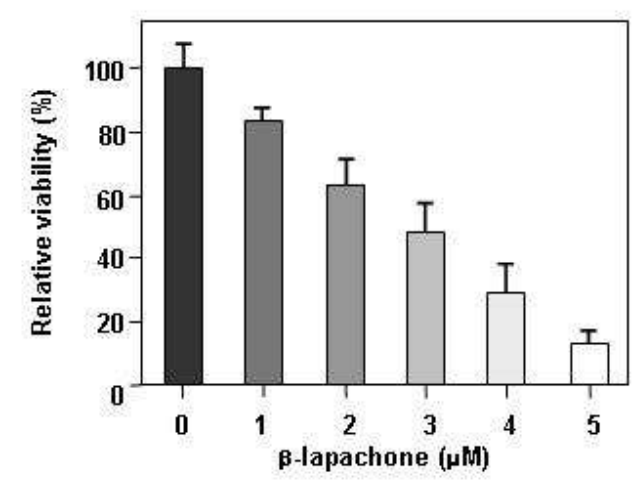

B)

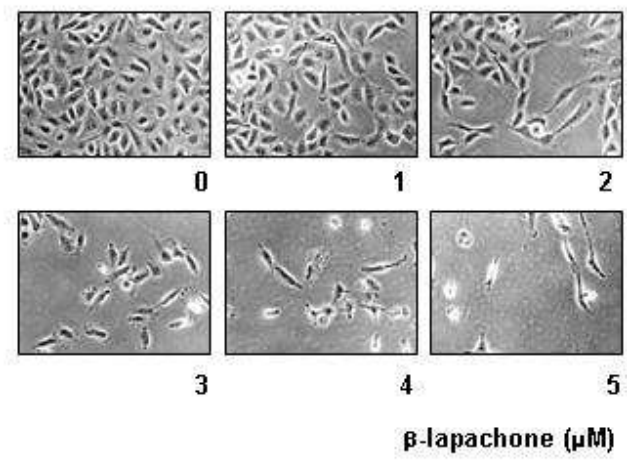

c)

B-lapachone ( $\mu \mathrm{M})$

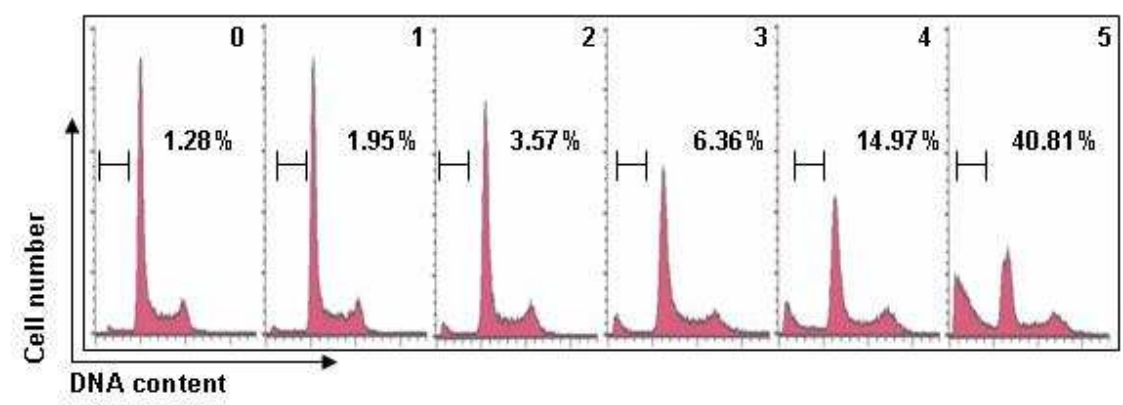

Fig. 1. Inhibition of the cell growth and induction of apoptosis by $\beta$-lapachone in A549 human lung cancer cells. (A) Cells were plated at $1 \times 10^{3}$ cells per $60-\mathrm{mm}$ plate, and incubated for $24 \mathrm{hr}$. The cells were treated with various concentrations of $\beta$-lapachone for $48 \mathrm{hr}$ and the viability was measured by the metabolic-dye-based MTT assay. Results are expressed as the means \pm S.D. of three independent experiments. (B) Cells were incubated with various concentrations of $\beta$-lapachone. After 48 hr incubation cells were sampled and examined under light microscopy. Magnification, X200. (C) Cells treated for $48 \mathrm{~h}$ with increasing concentration of $\beta$-lapachone. Then the cells were collected and stained with PI for flow cytometry analysis. The profile represents the increase of sub-G1 population and each point represents the mean of two independent experiments. 
A)

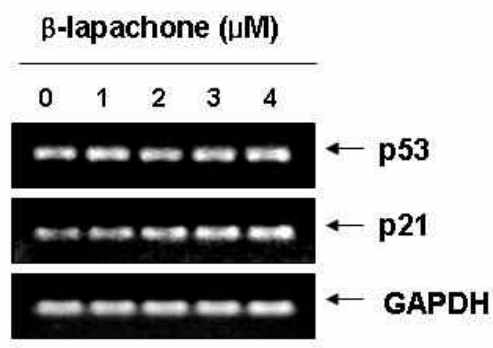

B)

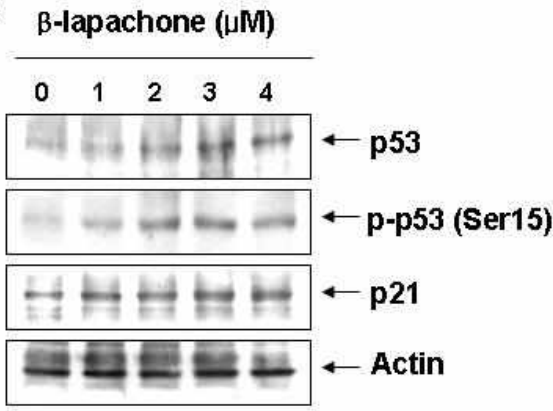

C)

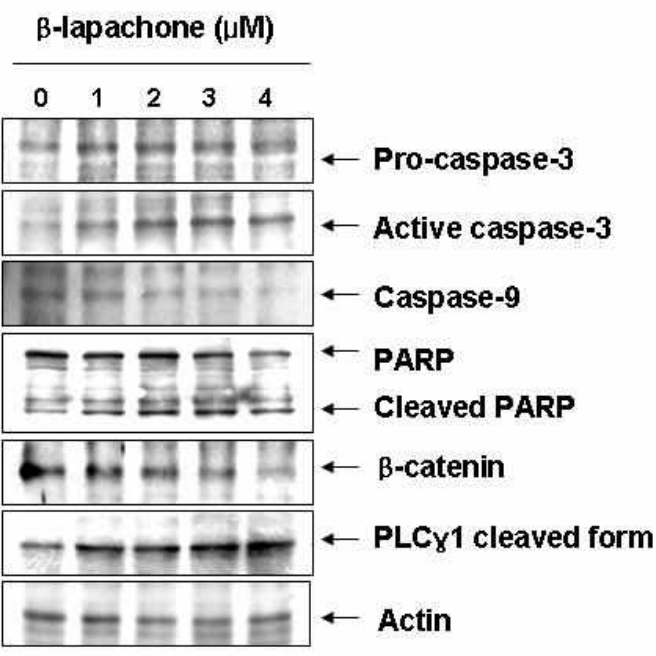

Fig. 2. Induction of p53 and p21, and activation of caspases by $\beta$-lapachone in A549 cells. (A) After 48 hr incubation with $\beta$-lapachone, total RNAs were isolated and reverse-transcribed. The resulting cDNAs were subjected to PCR with p53 and p21 primers and the reaction products were subjected to electrophoresis in 1\% agarose gel and visualized by EtBr staining. GAPDH was used as an internal control. (B) The cells were lysed and then cellular proteins were separated by SDS-polyacrylamide gels and transferred onto nitrocellulose membranes. The membranes were probed with the indicated antibodies. Proteins were visualized using an ECL detection system. Actin was used as an internal control.

sis 유발과정에서 $\mathrm{p} 53$ 의 증가에 의한 $\mathrm{p} 21$ 의 동방 상승현상을 보였던 결과[8,21,22]와는 유사한 현상이었지만, p53이 존재하 지 않거나 돌연변이된 세포에서는 나타나지 않는 현상[12,17] 으로 암세포의 종류에 따라 p53 및 p21의 발현 변화에 다소 차이가 있음을 알 수 있었다. 그러나 p53이 존재하는 세포에서 B-lapachone에 의한 p53의 인산화 증가는 Bax 발현 증가와도 연관성이 있을 것으로 기대되어 $\beta$-lapachone에 의한 인산화 형 p53의 발현 증가는 apoptosis 유도에 어느 정도 관여하고 있을 것으로 추정된다[3].

현재까지 보고된 ß-lapachone에 의한 대부분의 암세포 apoptosis 유도는 caspase 의존적으로 일어나는 것으로 알려 져 왔다. A549 폐암세포에서도 $\beta$-lapachone의 처리에 의한 apoptosis 유발이 caspase 활성 의존적인지의 여부를 조사하 기 위하여 caspase-3과 -9의 발현에 미치는 $\beta$-lapachone의 영 향을 조사한 결과, $\beta$-lapachone의 처리 농도가 증가할수록 활 성형 caspase-3의 발현이 증가되었으며, caspase-3의 상위 caspase에 속하는 caspase-9의 비활성형은 감소되어 B-lapachone 처리에 의하여 두 caspase가 모두 활성화되었음을 알 수 있었 다(Fig. 2C). 따라서 전형적인 caspase 의존적 apoptosis 유도 과정에서 활성화된 caspase- 3 의 표적 단백질로서 apoptosis가 일어났을 경우 단편화가 일어나는 poly(ADP-ribose) polymerase (PARP) 및 $\beta$-catenin의 발현에 미치는 $\beta$-lapachone의
영향을 조사하였다. Fig. 3에 나타낸 결과에서 알 수 있듯이 $\beta$-lapachone 처리 농도의 증가에 따라 3 가지 단백질의 발현 감소 또는 단편화된 단백질들의 발현이 증가되어 선행 연구들 의 결과와 유사한 경향성을 보였다[3,9,10,15,16,18].

최근 본 연구실에서 보고한 $\beta$-lapachone의 항염증 효능 결 과에서 $\beta$-lapachone은 lipopolysaccharide 자극에 의한 COX-2 의 발현을 선택적으로 저해하면서 $\mathrm{PGE}_{2}$ 의 생성을 억제하였으 며[13], 전립선 암세포의 증식억제 및 apoptosis 유도과정에서 COX-2의 발현 저하에 따른 $\mathrm{PGE}_{2}$ 생성 억제 현상이 동반됨을 관찰된 바 있다[9]. 따라서 B-lapachone에 의한 A549 세포의 apoptosis 유도과정에서 COXs의 발현변화에 따른 $\mathrm{PGE}_{2}$ 의 생 성 변화가 동반되는지를 조사하기 위하여 동일조건에서 배양 된 세포를 대상으로 COX-1 및 -2의 발현 변화를 조사하였다. Fig. $3 \mathrm{~A}$ 및 B의 결과에서 알 수 있듯이 COX-1의 mRNA 및 단백 질 발현에는 $\beta$-lapachone 처리가 별다른 영향을 미치니 못하였 으나, COX-2의 경우 전사 및 번역 수준에서 $\beta$-lapachone의 처리 농도 증가에 따라 점차적인 발현의 감소를 보여주었다. 이러한 3-lapachone에 의한 COX-2의 선택적 발현 저하가 $\mathrm{PGE}_{2}$ 의 생성 저하와 연관성이 있는지를 조사하기 위하여 $\mathrm{PGE}_{2}$ 의 생성에 미 치는 $\beta$-lapachone의 영향을 조사한 결과, $\beta$-lapachone의 처리 농도가 증가할수록 $\mathrm{PGE}_{2}$ 의 생성이 매우 감소되었으며, $\mathrm{PGE}_{2}$ 의 생성 감소 경향성은 COX-2의 발현 저하와 유사한 경향성을 보 
A) B-lapachone ( $(\mu \mathrm{M})$

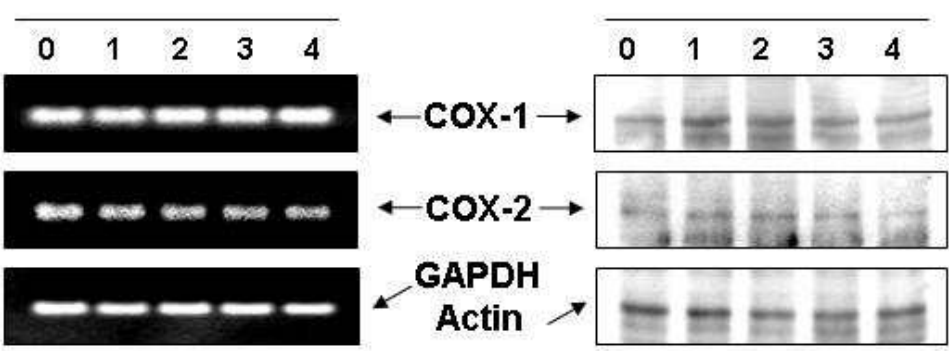

C)

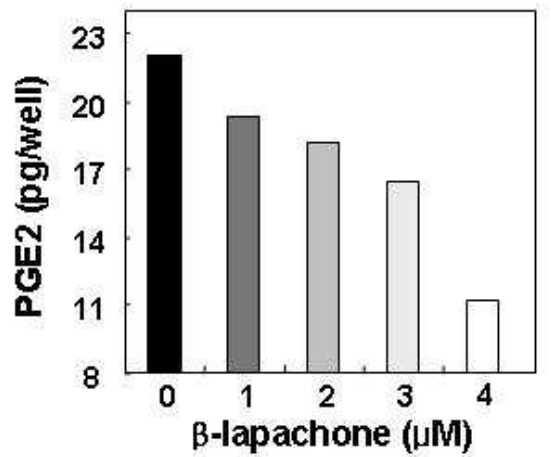

Fig. 3. Down-regulation of COX-2 expression and inhibition of $\mathrm{PGE}_{2}$ production in $\mathrm{A} 549$ cells after exposure to $\beta$-lapachone. (A) After $48 \mathrm{hr}$ incubation with $\beta$-lapachone, total RNAs were isolated and reverse-transcribed. The resulting cDNAs were subjected to PCR with COX-1 and COX-2 primers and the reaction products were subjected to electrophoresis in $1 \%$ agarose gel and visualized by EtBr staining. GAPDH was used as an internal control. (B) Cells were treated with the indicated concentrations of $\beta$-lapachone for $48 \mathrm{hr}$ and collected. The cells were lysed and then cellular proteins were separated by 10\% SDS-polyacrylamide gels. Proteins were visualized by Western blotting using anti-COX-1 and anti-COX-2 antibodies, and ECL detection. Actin was used as an internal control. (C) Cells were treated with the indicated concentrations of $\beta$ -lapachone for $48 \mathrm{hr}$ and collected. The $\mathrm{PGE}_{2}$ accumulation in the medium was determined by an EIA kit as described in materials and methods. Data represent the mean values of two independent experiments.

여주었다. 따라서 $\beta$-lapachone 처리에 의한 암세포의 증식 억제 에는 COX-2의 선택적 발현 억제에 의한 $\mathrm{PGE}_{2}$ 의 생성 저해와 연 관성이 있음을 알 수 있었다.

이상의 결과에서 B-lapachone에 의한 A549폐암세포의 증식 억제는 apoptosis 유도와 밀접한 연관성이 있었으며, 이는 p53 인산화에 의한 p21의 발현 증가와 caspase 활성 증가에 의한 것 임을 알 수 있었다. 또한 $\beta$-lapachone에 의한 A549 세포의 증식 억제 및 apoptosis 유도과정에서 관찰되는 $\mathrm{PGE}_{2}$ 의 생성억제는 COX-2의 선택적 발현 차단에 의한 것임을 알 수 있었다.

\section{감사의 글}

이 논문은 정부(교육과학기술부)의 재원으로 한국연구재단 의 지원을 받아 수행된 연구임(2010-0001730).

\section{References}

1. Anderson, W. F., A. Umar, J. L. Viner, and E. T. Hawk. 2002. The role of cyclooxygenase inhibitors in cancer prevention. Curr. Pharm 8, 1035-1062.

2. Choi, Y. H., H. S. Kang, and M. A. Yoo. 2002. Suppression of Human Prostate Cancer Cell Growth by $\beta$-lapachone via Inhibition of pRB Phosphorylation and Induction of Cdk inhibitor p21. J. Biochem Mol. Biol. 36, 223-229.

3. Choi, Y. H., M. J. Kim, S. Y. Lee, Y. N. Lee, G. Y. Chi, H. S. Eom, N. D. Kim, and B. T. Choi. 2002. Phosphorylation of p53, induction of Bax and activation of caspases during
B-lapachone-mediated apoptosis in human prostate epithelial cells. Int. J. Oncol. 21, 1293-1299.

4. Don, M. J., Y. H. Chang, K. K. Chen, L. K. Ho, and Y. P. Chau. 2001. Induction of CDK inhibitors (p21(WAF1) and p27(Kip1)) and Bak in the B-lapachone-induced apoptosis of human prostate cancer cells. Mol. Pharmacol. 59, 784-794.

5. Fujita, H., K. Koshida, E. T. Keller, Y. Takahashi, T. Yoshimito, M. Namiki, and A. Mizokami. 2002. Cyclooxygenase-2 promotes prostate cancer progression. Prostate 53, 232-240.

6. Gately, S. and R. Kerbel. 2003. Therapeutic potential of selective cyclooxygenase-2 inhibitors in the management of tumor angiogenesis. Prog. Exp. Tumor. Res. 37, 179-192.

7. Huang, L., and A. B. Pardee. 1999. B-lapachone induces cell cycle arrest and apoptosis in human colon cancer cells. Mol. Med 5, 711-720.

8. Hueber, A. P. Esser, K. Heimann, N. Kociok, S. Winter, and M. Weller. 1998. The topoisomerase I inhibitors, camptothecin and $\beta$-lapachone, induce apoptosis of human retinal pigment epithelial cells. Exp. Eye Res. 67, 525-530.

9. Lee, J. H., J. Cheong, Y. M. Park, and Y. H. Choi. 2005. Down-regulation of cyclooxygenase-2 and telomerase activity by $\beta$-lapachone in human prostate carcinoma cells. Pharmacol. Res. 51, 553-560.

10. Lee, J. I., D. Y. Choi, H. S. Chung, H. G. Seo, H. J. Woo, B. T. Choi, and Y. H. Choi. 2006. B-lapachone induces growth inhibition and apoptosis in bladder cancer cells by modulation of Bcl-2 family and activation of caspases. Exp. Oncol. 28, 30-35.

11. Li, C. J., L. Averboukh, and A. B. Pardee. 1993. B-Lapachone, a novel DNA topoisomerase I inhibitor with a mode of ac- 
tion different from camptothecin. J. Biol. Chem 268, 22463-22468.

12. Meng, R. D. and W. S. El-Deiry. 2001. p53-independent upregulation of KILLER/DR5 TRAIL receptor expression by glucocorticoids and interferon- $\gamma$. Exp. Cell Res. 262, 154-169.

13. Moon, D. O., Y. H. Choi, N. D. Kim, Y. M. Park, and G. Y. Kim. 2007. Anti-inflammatory effects of $\beta$-lapachone in lipopolysaccharide-stimulated BV2 microglia. Int. Immunopharmacol. 7, 506-514.

14. Noble, J. R., K. E. Willetts, W. E. Mercer, and R. R. Reddel. 1992. Effects of exogenous wild-type p53 on a human lung carcinoma cell line with endogenous wild-type p53. Exp. Cell Res. 203, 297-304.

15. Pink, J. J., S. M. Planchon, C. Tagliarino, M. E. Varnes, D. Siegel, and D. A. Boothman. 2000. NAD(P)H:Quinone oxidoreductase activity is the principal determinant of $\beta$ -lapachone cytotoxicity. J. Biol. Chem 275, 5416-5424.

16. Planchon, S. M., J. J. Pink, C. Tagliarino, W. G. Bornmann, M. E. Varnes, and D. A. Boothman. 2001. B-lapachone-induced apoptosis in human prostate cancer cells: involvement of NQO1/xip3. Exp. Cell Res. 267, 95-106.

17. Planchon, S. M., S. Wuerzberger, B. Frydman, D. T. Witiak, P. Hutson, D. R. Church, G. Wilding, and D. A. Boothman. 1995. B-lapachone-mediated apoptosis in human promyelocytic leukemia (HL-60) and human prostate cancer cells: a p53-independent response. Cancer Res. 55, 3706-3711.

18. Planchon, S. M., S. M. Wuerzberger-Davis, J. J. Pink, K. A. Robertson, W. G. Bornmann, and D. A. Boothman. Bcl-2 protects against $\beta$-lapachone-mediated caspase 3 activation and apoptosis in human myeloid leukemia (HL-60) cells. Oncol. Rep. 6, 485-492.

19. Schaffner-Sabba, K., K. H. Schmidt-Ruppin, W. Wehrli, A. R. Schuerch, and J.W. Wasley. 1984. B-lapachone: synthesis of derivatives and activities in tumor models. J. Med Chem 27, 990-994.

20. Weller, M., J. Rieger, C. Grimmel, E.G. Van Meir, N. De Tribolet, S. Krajewski, J. C. Reed, A. von Deimling, and J. Dichgans. 1998. Predicting chemoresistance in human malignant glioma cells: the role of molecular genetic analyses. Int. J. Cancer 79, 640-644.

21. Weller, M., S. Winter, C. Schmidt, P. Esser, A. Fontana, J. Dichgans, and P. Groscurth. 1997. Topoisomerase-I inhibitors for human malignant glioma: differential modulation of p53, p21, bax and bcl-2 expression and of CD95-mediated apoptosis by camptothecin and $\beta$ -lapachone. Int. J. Cancer 73, 707-714.

22. Wuerzberger, S. M., J. J. Pink, S. M. Planchon, K. L. Byers, W. G. Bornmann, and D. A. Boothman. 1998. Induction of apoptosis in MCF-7:WS8 breast cancer cells by $\beta$-lapachone. Cancer Res. 58, 1876-1885.

\section{초록 : $\beta$-lapachone에 의한 A549 인체폐암세포의 apoptosis 유도와 cyclooxygenase-2 활성 저하 최영현*}

(동의대학교 한의과대학 생화학교실, 대학원 바이오물질제어학과(BK21 Program) 및 블루바이오소재개발센터)

B-lapachone은 남미에 자생하는 lapacho 나무(Tabeuia avellaneda)의 수액에 함유된 quinone계열의 일종으로 많은 인체암세포에서 apoptosis를 유발하는 것으로 알려져 있다. 본 연구는 A549 인체폐암세포를 대상으로 $\beta$ -lapachone에 의한 apoptosis 유발 과정에서 나타나는 또 다른 현상들을 조사하기 위하여 실시되었다. $\beta$ -lapachone이 처리된 A549 세포는 처리 농도의 증가에 따라 생존율이 감소되었으며, 이는 apoptosis 유발과 연관 이 있음을 MTT assay와 flow cytometry 분석을 통하여 확인하였다. B-lapachone에 의한 A549 세포의 증식억제 는 종양억제유전자 p53과 cyclin-dependent kinase 저해제인 p21의 발현을 전사 및 번역 수준에서 증가시켰으며, p53 단백질의 인산화 증가와 연관성이 있었다. 또한 $\beta$-lapachone은 caspase-3과 -9를 활성화시켰으며, 활성화된 caspase-3의 기질 단백질들[poly(ADP-ribose) polymerase, $\beta$-catenin 및 phospholipase C-81]의 단편화를 유도하 였다. 아울러 $\beta$-lapachone은 cyclooxygenase (COX)-2의 mRNA 및 단백질의 발현을 억제하였으나 COX-1의 발현 에는 영향을 미치지 않았으며, $\beta$-lapachone에 의한 COX-2의 발현억제는 prostaglandin $\mathrm{E}_{2}$ 의 생성 저하에 관련이 있었다. 본 연구의 결과는 $\beta$-lapachone의 항암활성 기전의 이해와 더불어 $\beta$-lapachone이 폐암세포에서 강력한 항암활성이 있음을 보여 주는 것이다. 